No 3981

Studia nad Autorytaryzmem i Totalitaryzmem 42, nr 1

Wrocław 2020

https://doi.org/10.19195/2300-7249.42.1.4

MICHAŁ URBAŃCZYK

ORCID: 0000-0003-4387-2848

Uniwersytet im. Adama Mickiewicza w Poznaniu

mur@amu.edu.pl

\title{
Definiowanie mowy nienawiści w orzecznictwie sądów polskich w sprawach karnych
}

\begin{abstract}
Abstrakt: Celem artykułu jest próba odpowiedzi na pytanie, w jaki sposób mowa nienawiści jest definiowana w języku prawniczym. Realizacji tego zadania służy analiza wybranych orzeczeń Sądu Najwyższego, Trybunału Konstytucyjnego oraz sądów powszechnych, wydanych w sprawach karnych. W kontekście karnoprawnym do zdefiniowania omawianego zjawiska istotne jest zrozumienie takich zwrotów, jak ,publiczne propagowanie faszystowskiego lub innego totalitarnego ustroju państwa”, „publiczne nawoływanie do nienawiści na tle różnic narodowościowych, etnicznych, rasowych, wyznaniowych albo ze względu na ateizm” oraz „,publiczne znieważenie grupy ludności albo poszczególnej osoby z powodu jej przynależności narodowej, etnicznej, rasowej, wyznaniowej albo z powodu jej bezwyznaniowości”. Na podstawie zawartych w artykule rozważań wskazany zostanie sposób pojmowania i definiowania mowy nienawiści mający zastosowanie w języku prawniczym.
\end{abstract}

Słowa kluczowe: mowa nienawiści, nawoływanie do nienawiści, propagowanie ustroju totalitarnego, język prawniczy, znieważenie, symbole nazistowskie, swastyka.

\section{DEFINING HATE SPEECH IN THE CASE LAW OF POLISH COURTS IN PENAL CASES}

\section{Abstract}

The aim of this article is to answer the question of how hate speech is defined in legal language. The analysis of selected decisions of the Supreme Court, Constitutional Tribunal and common courts issued in criminal cases serves the purpose of the above-mentioned task. In the criminal-law context, it is important to understand such phrases as "public promotion of a fascist or other totalitarian state system", "public incitement to hatred on the grounds of national, ethnic, racial, religious, or atheistic differences" and "publicly insulting a group of people or an individual because of their national, ethnic, racial, religious, or atheistic affiliation" to define this phenomenon. Based on the above considerations, the manner of understanding and defining the speech of hatred applicable within the legal language will be indicated.

Keywords: hate speech, incitement to hatred, promotion of the totalitarian system, legal lan-

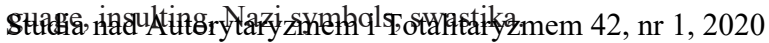

(C) for this edition by CNS 
Punktem wyjścia poniższych rozważań jest założenie, że mowa nienawiści, jako pewne zjawisko ze sfery społecznej i politycznej, ma swoje odzwierciedlenie w sferze prawnej. Dlatego celem badawczym artykułu jest wskazanie, jak jest ona pojmowana i definiowana w języku prawniczym. Autor jako pole badawcze wyznaczył kontekst karnoprawny, intuicyjnie najbliższy mowie nienawiści. W tym aspekcie przeprowadzono analizę wybranych orzeczeń Sądu Najwyższego, Trybunału Konstytucyjnego i sądów powszechnych w sprawach karnych.

Mając świadomość, że szeroko rozumiana mowa nienawiści obejmuje wiele przestępstw, jak pochwalanie przestępstwa, nawoływanie do popełnienia przestępstwa, bezdyskusyjne jest, że za najistotniejsze uznać trzeba art. 256 i 257 k.k. Do nich autor postanowił zawęzić swoją analizę (analizy innych przestrzeni prawa karnego oraz kolejnych gałęzi prawa autor zamierza dokonać w następnych artykułach poświęconych temu problemowi), skupiając się na przestępstwach publicznego propagowania faszystowskiego lub innego totalitarnego ustroju państwa, publicznego nawoływania do nienawiści na tle różnic narodowościowych, etnicznych, rasowych, wyznaniowych albo ze względu na bezwyznaniowość i publicznym znieważeniu grupy ludności albo danej osoby z powodu jej przynależności narodowej, etnicznej, rasowej, wyznaniowej lub z powodu jej bezwyznaniowości.

Dwa pierwsze zwroty zawarte są w art. 256 k.k., penalizującym przestępstwo publicznego propagowania faszyzmu i nawoływania do nienawiści ${ }^{1}$, trzeci zwrot to element art. 257 k.k., penalizującego publiczne znieważenie lub naruszenie nietykalności z powodów narodowościowych, etnicznych, rasowych i wyznaniowych lub bezwyznaniowości ${ }^{2}$. Te dwa artykuły, zarówno w debatach publicystycznych, jak i tych o charakterze naukowym (prawnych, politologicznych czy socjologicznych $)^{3}$, traktowane są właśnie jako przepisy penalizujące mowę nie-

1 Art. 256 k.k.: „§ 1. Kto publicznie propaguje faszystowski lub inny totalitarny ustrój państwa lub nawołuje do nienawiści na tle różnic narodowościowych, etnicznych, rasowych, wyznaniowych albo ze względu na bezwyznaniowość, podlega grzywnie, karze ograniczenia wolności albo pozbawienia wolności do lat 2 . $§ 2$. Tej samej karze podlega, kto w celu rozpowszechniania produkuje, utrwala lub sprowadza, nabywa, przechowuje, posiada, prezentuje, przewozi lub przesyła druk, nagranie lub inny przedmiot, zawierające treść określoną w $\S 1$ albo będące nośnikiem symboliki faszystowskiej, komunistycznej lub innej totalitarnej [przepis utracił moc w części obejmującej wyrazy ,albo będące nośnikiem symboliki faszystowskiej, komunistycznej lub innej totalitarnej” — M.U.]. § 3. Nie popełnia przestępstwa sprawca czynu zabronionego określonego w $\S 2$, jeżeli dopuścił się tego czynu w ramach działalności artystycznej, edukacyjnej, kolekcjonerskiej lub naukowej. § 4. W razie skazania za przestępstwo określone w $\S 2$ sąd orzeka przepadek przedmiotów, o których mowa w $\S 2$, chociażby nie stanowiły własności sprawcy".

2 Art. 257 k.k.: „Kto publicznie znieważa grupę ludności albo poszczególną osobę z powodu jej przynależności narodowej, etnicznej, rasowej, wyznaniowej albo z powodu jej bezwyznaniowości lub z takich powodów narusza nietykalność cielesną innej osoby, podlega karze pozbawienia wolności do lat 3".

3 Pełne spektrum definicji mowy nienawiści w polskiej debacie wraz z odniesieniami do doświadczeń zagranicznych zob. E. Rogalska, M. Urbańczyk, Złożoność zjawiska mowy nienawiści

Studia nad Autorytaryzmem i Totalitaryzmem 42, nr 1, 2020

(C) for this edition by CNS 
nawiści ${ }^{4}$. Opierając się na dotyczących ich rozważaniach, wskazany zostanie sposób pojmowania i definiowania mowy nienawiści mający zastosowanie w języku prawniczym.

Dla jasności wywodu konieczne jest podkreślenie kilku wstępnych kwestii. Po pierwsze, w samym języku prawnym brakuje definicji mowy nienawiści. Ustawy posługują się innymi (wymienionymi wcześniej) zwrotami, co rodzi określone konsekwencje (przykładowo wskazuje, że termin „mowa nienawiści” został zapożyczony z innych porządków prawnych ${ }^{5}$ ). Poza tym termin ten nie występuje w komentarzach do kodeksu karnego (co z kolei dowodzi, że jest on stosunkowo nowy dla polskiej doktryny prawa karnego ${ }^{6}$. Jest natomiast stosowany w ramach debaty publicznej oraz licznych kontekstach pozaprawnych. Te pozaprawne definicje są cytowane zarówno przez sądy, jak i naukę prawa. W ten sposób termin „mowa nienawiści” staje się zakorzeniony w języku prawniczym, o czym świadczy jego występowanie chociażby w treści wyroków sądowych. Jednak - co trzeba podkreślić już na wstępie — jego pojmowanie jest niejednorodne.

Po drugie, wspomniany szerszy kontekst to występowanie mowy nienawiści w sferze publicznej (w debacie politycznej, mediach społecznościowych itp.).

w pozaprawnym aspekcie definicyjnym, „Studia nad Autorytaryzmem i Totalitaryzmem” 39, 2017, nr 2, s. 117-135.

4 Autor skłania się ku hipotezie, że w kodeksie karnym znaleźć można inne przepisy, które także mogą penalizować określone czyny kwalifikujące się jako mowa nienawiści. Są to: art. 255 k.k. penalizujący nawoływanie do przestępstwa, art. 126a k.k. penalizujący publiczne nawoływanie do popełnienia czynu określonego w art. 118, 118a, $119 \S 1$, art. 120-125 lub publiczne pochwalanie popełnienie czynu określonego w tych przepisach. Artykuł 118 k.k. dotyczy ludobójstwa (eksterminacji), art. 118a k.k. — masowego zamachu na grupę ludności, art. 119 k.k. — przemocy i groźby bezprawnej ze względu na przynależność narodową, etniczną, rasową, polityczną, wyznaniową lub z powodu bezwyznaniowości, art. 120 k.k. - stosowania środków masowej zagłady, art. 122 k.k. — niedopuszczalnych ataków i sposobów walki w czasie działań zbrojnych.

5 Jeszcze w 2012 roku poseł na Sejm RP Ryszard Kalisz (SLD) stwierdził w trakcie dyskusji nad nowelizacją kodeksu karnego, iż zwrot „mowa nienawiści został sformułowany przez doktrynę nie tak dawno temu" - Wypowiedzi na posiedzeniach Sejmu. Posiedzenie nr 15 w dniu 24-052012 (2. dzień obrad), http://www.sejm.gov.pl/sejm7.nsf/wypowiedz.xsp?posiedzenie=15\&dzie$\mathrm{n}=2 \& w y \mathrm{p}=124$ (dostęp: 20.12.2018).

${ }^{6}$ Nie posługuje się nim Marek Bojarski w Systemie Prawa Karnego z 2018 roku pod redakcją Lecha Gardockiego. W komentarzach do kodeksu karnego nie posługują się nim: Marek Mozgawa, Arkadiusz Lach w komentarzu pod redakcją Violetty Konarskiej-Wrzosek, Zbigniew Ćwiąkalski i Michał Kalitowski w komentarzu Mariana Filara, Joanna Piórkowska-Flieger w komentarzu Tadeusza Bojarskiego, Zbigniew Ćwiąkalski w komentarzu Andrzeja Zolla, Andrzej Marek i Michał Kalitowski w komentarzu Oktawii Górniok czy Ryszard A. Stefański. Nie odnajdziemy go w tak zwanych dużych komentarzach Becka pod redakcją Michała Królikowskiego i Roberta Zawłockiego czy pod redakcją Andrzeja Wąska ani w komentarzu kompaktowym pod redacją Alicji Grześkowiak i Krzysztofa Wiaka, ani w komentarzu BeckOK R.A. Stefańskiego; nie ma go także w krótkich komentarzach Becka Bartłomieja Gadeckiego. Jedynie Dagmara Gruszecka, pisząc o przedmiocie ochrony art. 257 k.k., podkreśliła, że ,[p]rawnokarna ochrona przed tzw. przestępstwami popełnianymi z nienawiści (hate crimes) stanowi jeden z elementów antydyskryminacyjnej polityki państwa demokratycznego" — eadem, [w:] Kodeks karny. Czesść szczególna. Komentarz, red. J. Giezek, LEX 2014.

Studia nad Autorytaryzmem i Totalitaryzmem 42, nr 1, 2020

(C) for this edition by CNS 
Zjawisko to ma zatem kontekst znacząco rozleglejszy aniżeli wyłącznie aspekty prawne. Czym innym będzie bowiem przestępstwo mowy nienawiści, a czym innym akt mowy nienawiści niebędący przestępstwem (który dla celów roboczych określony zostanie jako ,akt języka pogardy”), tak jak czym innym są przestępstwa $\mathrm{z}$ nienawiści ${ }^{7} \mathrm{i}$ incydenty $\mathrm{z}$ nienawiści (które przestępstwami nie są).

Po trzecie, tak jak w sferze publicznej, w sferze języka prawniczego mamy do czynienia z wielością terminów, które pojawiają się w kontekście mowy nienawiści, (przykładowo ,język nienawiści”). Za istotne dla omawianego problemu należy uznać także to, że w wielu orzeczeniach nie tyle definiuje się mowę nienawiści, ile jedynie wskazuje, że dana wypowiedź ma taki charakter. Takie przykłady także zostaną wskazane jako egzemplifikacje zjawiska mowy nienawiści, gdyż będą pomocne w rozważaniach podsumowujących niniejszy artykuł.

Wskazane problemy wymagają pewnego założenia wstępnego, to jest wskazania podziału na mowę nienawiści $\mathrm{w}$ wąskim znaczeniu i mowę nienawiści w znaczeniu szerokim. W pierwszym wypadku mowa jest wyłącznie o przestępstwach określonych art. 256 i 257 k.k. W związku z tym mowa nienawiści w wąskim znaczeniu to publiczne propagowanie faszystowskiego lub innego totalitarnego ustroju państwa, publiczne nawoływanie do nienawiści na tle różnic narodowościowych, etnicznych, rasowych, wyznaniowych albo ze względu na bezwyznaniowość oraz publiczne znieważenie grupy ludności albo poszczególnej osoby z powodu jej przynależności narodowej, etnicznej, rasowej, wyznaniowej albo z powodu jej bezwyznaniowości. Natomiast w znaczeniu szerokim mowa nienawiści to każda wypowiedź obecna w sferze publicznej, która ma charakter znieważający, poniżający lub która w swej treści nawołuje do nienawiści w stosunku do kogoś z powodu jego przynależności do określonej grupy ${ }^{8}$ (na przykład mniejszości seksualnej). W tym szerszym znaczeniu będzie więc chodzić zarówno o mowę nienawiści w znaczeniu wąskim, jak i wskazany wyżej język pogardy, to jest akty mowy nienawiści niebędące przestępstwem.

\section{Publiczne propagowanie faszystowskiego lub innego totalitarnego ustroju państwa}

W kontekście zwrotu ,publiczne propagowanie faszystowskiego lub innego totalitarnego ustroju państwa" za kluczowy element do zdefiniowania mowy

7 Przykładowo autorzy Informatora Statystycznego Wymiaru Sprawiedliwości posługują się szerszym terminem ,przestępstwa z nienawiści”, wskazując na przestępstwa z art. $118 \S 1$, §2

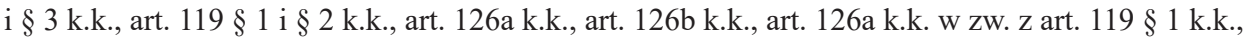
art. 194 k.k., art. $195 \S 1$ i $~ 2$, art. 196 k.k., art. 256 § 1 i $\S 2$ k.k. oraz art. 257 k.k.; por. Informator Statystyczny Wymiaru Sprawiedliwości, Opracowania wieloletnie, https://isws.ms.gov.pl/pl/baza-statystyczna/opracowania-wieloletnie (dostęp: 31.12.2018).

8 E. Rogalska, M. Urbańczyk, op. cit., s. 132.

Studia nad Autorytaryzmem i Totalitaryzmem 42, nr 1, 2020

(C) for this edition by CNS 
nienawiści w wąskim znaczeniu należy uznać termin „propagować”. Znaczenie pozostałych pojęć jest już bowiem utrwalone w doktrynie prawa i nie wymaga w tym miejscu obszerniejszych rozważań. Jedynie na marginesie warto wskazać na kilka kwestii.

Z „publicznym” zachowaniem się sprawcy mamy do czynienia, gdy rozpowszechniana opinia jest dostępna dla bliżej nieokreślonej liczby osób. Jak podkreśla się w doktrynie prawa karnego, jest tak także wtedy, gdy sprawca kieruje „swe przesłanie nie do wszystkich osób, które mogą się z nim zapoznać, ale do pewnych grup osób" ". Samo publiczne działanie nie jest jednak równoznaczne z bezpośrednim kontaktem „między sprawcą a osobami, do których kieruje on swój przekaz" ${ }^{\prime 10}$. Ponadto w celu wskazania publicznego charakteru działania nie jest konieczne, aby dokonywano go w miejscu publicznym, wystarczy, aby treści, które działający chce rozpowszechnić, mogły dotrzeć do bliżej nieokreślonego zbioru odbiorców. Terminy „faszystowski” oraz „totalitarny” ustrój państwa również nie mają charakteru spornego. Jak zauważył Sąd Najwyższy, znaczenie zwrotu „ustrój totalitarny”"11 jest wśród historyków ,utrwalone i można tu mówić o notorium sądowym" 12 . Powszechnie rozumie się pod tym pojęciem faszystowski, nazistowski i komunistyczny system polityczny.

Odnosząc się do terminu ,propagować”, przede wszystkim warto przedstawić wykładnię, jaką Sąd Najwyższy zawarł w uchwale z 2002 roku. Po pierwsze, zwrócił on uwagę na różnice w znaczeniu między terminem ,propaguje” a „pochwala", użytym zarówno w art. $270 \S 2^{13}$, jak i art. $272^{14}$ k.k. z 1969 roku. Sąd uznał bowiem, że ,propagowanie może, ale nie musi być połączone z pochwalaniem. Można bowiem coś publicznie pochwalać bez zamiaru propagowania, jak

9 A. Michalska-Warias, [w:] Kodeks karny. Część szczególna, red. M. Królikowski, R. Zawłocki, t. 2, Warszawa 2013, s. 324.

10 J. Bafia, K. Mioduski, M. Siewierski, Kodeks karny, Warszawa 1977, s. 475.

11 Najbardziej uniwersalną i popularną typologię cech, jakie miał reżim totalitarny, sporządzili jeszcze w latach sześćdziesiątych amerykańscy politolodzy Carl J. Friedrich i Zbigniew Brzeziński: „Syndrom, czyli zespół powiązanych cech dyktatur totalitarnych składał się z ideologii, jednej partii kierowanej na ogół przez jednostkę, terrorystycznej policji, monopolu komunikacji, monopolu broni, centralnie kierowanej gospodarki. [...] Sześć podstawowych cech, które według nas tworzą szczególny model totalitarnej dyktatury, tworzą zbiór cech, które przeplatają się i wzajemnie wspierają, jak to ma miejsce w »,organicznych « systemach. Nie można więc rozpatrywać ich w izolacji i dokonywać porównań w oderwaniu od innych" — eidem, Dyktatura totalitarna, [w:] Wtadza i polityka. Wybór tekstów ze współczesnej politologii zachodniej, red. M. Ankwicz, Warszawa 1986, s. 210.

12 Postanowienie SN z dnia 1 września 2011 roku, sygn. V KK 98/11, LEX nr 950444.

13 Art. 270 ustawy z dnia 19 kwietnia 1969 roku - Kodeks karny (Dz.U. Nr 13, poz. 94 z późn. zm.; dalej: k.k. 1969): „§ 1. Kto publicznie lży, wyszydza lub poniża Naród Polski, Polską Rzeczpospolitą Ludową, jej ustrój lub naczelne organy, podlega karze pozbawienia wolności od 6 miesięcy do lat 8. § 2. Tej samej karze podlega, kto publicznie pochwala faszyzm lub jakąkolwiek jego odmianę".

14 Art. 272 k.k. 1969: „Kto publicznie nawołuje do waśni na tle różnic narodowościowych, etnicznych, rasowych lub wyznaniowych albo takie waśnie publicznie pochwala, podlega karze pozbawienia wolności od 6 miesięcy do lat 5".

Studia nad Autorytaryzmem i Totalitaryzmem 42, nr 1, 2020

(C) for this edition by CNS 
i propagować, nie pochwalając tego, co się propaguje"15. W ten sposób odrzucił pogląd, wedle którego terminy te oznaczają tę samą czynność albo mają charakter bliskoznaczny. Odwołując się do znaczenia słownikowego, Sąd Najwyższy wskazał, że ,propagow anie w języku polskim oznacza przede wszystkim upowszechnianie, szerzenie czegoś, w tym także poglądu, aby do tego kogoś przekonać”, w rozumieniu zaś art. 256 k.k. — „każde publiczne zachowanie, które stanowi upowszechnianie faszystowskiego lub innego totalitarnego ustroju państwa, podjęte w celu przekonania do niego" 16 .

W dalszej części swych rozważań SN wskazał na utrwalone w doktrynie prawa karnego podstawowe elementy pojmowania „propagowania”. Oznacza ono bowiem ,szerzenie wiedzy o totalitarnym ustroju państwa i popieranie go, zachęcanie do wprowadzenia tego właśnie ustroju, podkreślanie jego zalet i przemilczanie wad"17. Sąd Najwyższy zauważył, że w literaturze przedmiotu wskazuje się także na sytuacje, w których nie można mówić o propagowaniu w rozumieniu art. 256 k.k. Propagowaniem nie jest, po pierwsze, samo prezentowanie zasad takiego ustroju, pozbawione angażowania się po jego stronie ${ }^{18}$. Po drugie, nie można za propagowanie uznać cytowania i publikowania artykułów i książek autorów gloryfikujących lub propagujących taki ustrój, jeżeli ich publikacja miała inne cele niż jego propagowanie ${ }^{19}$ (zwłaszcza z krytycznym komentarzem ${ }^{20}$ ). Wreszcie po trzecie, nie mamy do czynienia z tym zjawiskiem, gdy prezentowanie takiego ustroju ma służyć jedynie manifestacji osobistych poglądów, a nie przekonywaniu kogokolwiek ${ }^{21}$. O ile dwie pierwsze kategorie wydają się bezsporne (pierwsza ma bowiem charakter przekazywania informacji, druga dotyczy szeroko pojętej działalności naukowej czy popularnonaukowej), o tyle wydaje się, że pewne problemy w praktyce orzeczniczej może budzić trzecia kategoria. Zdaje się bowiem, że niezwykle rzadkie będą sytuacje, w których publicznej manifestacji osobistych poglądów (niebędących krytyką systemu totalitarnego ani przekazywaniem informacji lub rozpowszechnianiem wiedzy naukowej) nie będzie towarzyszyć chęć przekonania osób trzecich do swoich racji.

15 Uchwała SN z dnia 28 marca 2002 roku, sygn. I KZP 5/02, OSNKW 2002/5-6/32, LEX nr 51722.

16 Ibidem.

17 A. Zoll, Kodeks karny. Część szczególna, t. 2, Kraków 1999, s. 915.

18 J. Wojciechowski, Kodeks karny. Komentarz. Orzecznictwo, Warszawa 2000, s. 487.

19 L. Gardocki, Prawo karne, Warszawa 2001, s. 287.

20 Na marginesie warto wskazać problemy polskich wydawców Mein Kampf Adolfa Hitlera. Dopiero drugie wydanie Mojej walki w języku polskim (Wydawnictwa Książki Niezwykłej „XXL”) z 2005 roku zaopatrzone było w komentarz historyczny autorstwa Bogdana Michalskiego (zob. A. Hitler, Mein Kampf. Moja walka, Wrocław 2005, 205 s.), podczas gdy pierwsze wydanie (wydawnictwa Werset) z 1992 roku takowego wstępu nie zawierało, co skutkowało problemami prawnymi wydawnictwa, oskarżonego o propagowanie nazizmu (por. idem, Moja walka, Kraków 1992, 284 s.).

21 M. Flemming, W. Kutzmann, Przestęstwa przeciwko porządkowi publicznemu, Warszawa 1999, s. 66.

Studia nad Autorytaryzmem i Totalitaryzmem 42, nr 1, 2020

(C) for this edition by CNS 
Warto na marginesie dodać, że w wyrokach sądów powszechnych wskazuje się ponadto, że

propagowanie obejmuje nie tylko działania adresowane do osób, które z danym zagadnieniem, ideologią, dotychczas nie spotkały się, ale także wobec tych, którzy są jej świadomymi odbiorcami, zwolennikami i w taki sposób utwierdzani są w słuszności własnych, tak propagowanych poglądów ${ }^{22}$.

Propagowanie nie musi być zatem skierowane do osób przypadkowych, lecz także do tych, które z danymi opiniami są zaznajomione i często już się z nimi identyfikują. Zasadniczo Sąd Najwyższy stanął na stanowisku, że

wykładnia językowa prowadzi do wniosku, że propagowanie oznacza prezentowanie tego rodzaju ustroju, co może mieć postać każdego zachowania, którego treścią jest rozpowszechnianie wiedzy dotyczącej ustroju państwa totalitarnego, a więc także wystawienie na widok publiczny symboli takiego państwa czy też wykonywanie określonych gestów identyfikowanych z takim ustrojem ${ }^{23}$.

W orzeczeniach sądów powszechnych zwraca się w tym kontekście uwagę na następujące kwestie.

Przede wszystkim czym innym jest wyłącznie identyfikowanie się z określonymi poglądami. Jak zauważył Sąd Apelacyjny w Warszawie, propagowanie określonych poglądów to

działania jakościowo inne aniżeli samo identyfikowanie się z nimi, to popieranie, zachęcanie, podkreślanie zalet i jednoczesne ignorowanie wad. Propagowanie poglądów wykracza poza ich wyznawanie, skoro jego istota sprowadza się do zachęcania innych do ich poznania i przyjęcia za własne 24 .

Ma to miejsce w sytuacji, gdy dana osoba przechowuje w celu rozpowszechniania treści i nośniki propagujące ustrój totalitarny, niszczy ośrodki kultu religijnego, dokonuje motywowane takimi poglądami czyny godzące w zdrowie i życie ludzkie, rozwiesza plakaty i wlepki o treściach wrogich wobec osób innej narodowości, umieszcza napisy i symbole faszystowskie na budynkach czy bierze udział w manifestacjach i koncertach, na których wznoszone są okrzyki o treściach nazistowskich, prezentowane są symbole i gesty faszystowskie ${ }^{25}$.

W wypadku mowy nienawiści w wąskim zakresie w kontekście ,propagowania” problemem, który częstokroć sąd musi rozstrzygnąć, jest kwestia używania w przestrzeni publicznej określonych znaków i symboli. Wydawać by się mogło, że problemu tego nie ma w przypadku symboli bezpośrednio związanych z totalitarnym

22 Wyrok SA w Warszawie II Wydział Karny z dnia 30 maja 2018 roku, sygn. II AKa 432/17, https://sip.lex.pl/orzeczenia-i-pisma-urzedowe/orzeczenia-sadow/ii-aka-432-17-razaca-niewspolmiernosc-kary-wyrok-sadu-522638893 (dostęp: 20.05.2020).

23 Uchwała SN z dnia 28 marca 2002 roku.

24 Wyrok SA w Warszawie II Wydział Karny z dnia 30 maja 2018 roku.

25 Ibidem.

Studia nad Autorytaryzmem i Totalitaryzmem 42, nr 1, 2020

(C) for this edition by CNS 
systemem nazistowskich Niemiec: swastyki i liter $\mathrm{SS}^{26}$. Jak zauważył Sąd Apelacyjny w Warszawie w 2018 roku, określona symbolika i gesty

są utożsamiane wyłącznie $\mathrm{z}$ ideologią faszystowską, bowiem dla potrzeb jej propagowania zostały stworzone bądź zaadoptowane i ich wymowa, nawet dla osoby o podstawowej wiedzy, jest jednoznaczna. Symbole te, [...] prezentowane na manifestacjach, umieszczane na budynkach czy eksponowane publicznie w innych okolicznościach, służą wyłącznie propagowaniu wskazanej ideologii, bowiem niezależnie od tego, jakie jest ich historyczne źródło, w tym celu są używane i w świadomości odbiorców tak tylko identyfikowane ${ }^{27}$.

Jednocześnie jednak trzeba przywołać orzeczenie Sądu Apelacyjnego w Katowicach z 2005 roku, w którym stwierdzono, że zachowanie ,polegające na noszeniu kurtek z naszywkami na rękawie i kołnierzu przedstawiających swastykę nie nosi znamion przestępstwa $\mathrm{z}$ art. 256 k.k." 28 . Orzeczenie to stoi w sprzeczności z cytowanymi wcześniej twierdzeniami Sądu Najwyższego z 2002 roku, który wskazał, że „może mieć [propagowanie - M.U.] postać każdego zachowania [...], a więc także wystawienia na widok publiczny symboli takiego państwa"29. Sąd podkreślił jednak, że zależy to „od niepowtarzalnych okoliczności konkretnego zdarzenia".

Autor stoi na stanowisku, że w euroatlantyckim kręgu kulturowym ze względu na ludobójczy charakter nazizmu i popełnione przez niemiecką Trzecią Rzeszę zbrodnie w czasie II wojny światowej trudno dopuszczać używanie swastyki w sferze publicznej w jakimkolwiek kontekście z wyjątkiem naukowego czy artystycznego ${ }^{30}$. Jeśli zatem wzmiankowane naszywki nie były elementem strojów członków grup rekonstrukcyjnych albo nie były przekreślone, trudno uznać ten wyrok za słuszny.

Wbrew stwierdzeniu Sądu Apelacyjnego w Warszawie z 2018 roku (który raczej miał na myśli symbolikę nazistowską) pojawienie się w sferze publicznej symbolu używanego przez faszystowskie Włochy, to jest fasces, czyli pęku rózg liktorskich z wetkniętym za nie toporkiem, nie zawsze wiąże się z propagowaniem tej ideologii. Jest to bowiem symbol głęboko zakorzeniony w kulturze starożytnego Rzymu i jako metafora hasła E pluribus unum (łac. „z wielu jeden”) jest bardzo obecny w kulturze Stanów Zjednoczonych Ameryki ${ }^{31}$ (jako przykład można wskazać salę plenarną Izby Reprezentantów USA czy wejście do chica-

26 SS — skrót od die Schutzstaffeln der NSDAP (Sztafety Ochronne NSDAP).

27 Wyrok SA w Warszawie II Wydział Karny z dnia 30 maja 2018 roku.

28 Wyrok SA w Katowicach z dnia 4 sierpnia 2005 roku, sygn. II AKa 251/05, LEX nr 167924.

29 Por. przyp. 22.

${ }^{30} \mathrm{Z}$ drugiej jednak strony trudno nie patrzeć krytycznie na eliminację swastyki ze sfery popkultury w konkretnych kontekstach historycznych jak w wypadku niektórych gier komputerowych, których akcja dzieje się w czasie II wojny światowej.

31 Sam pęk rózg jest jeszcze bardziej rozpowszechniony — znajduje się nad drzwiami wyjściowymi w Gabinecie Owalnym, a także towarzyszy Abrahamowi Lincolnowi przed wejściem do jego mauzoleum, pomnikom Jerzego Waszyngtona czy Aleksandra Hamiltona. W tym wypadku nie ma jednak mowy o nawiązaniach do włoskiego faszyzmu.

Studia nad Autorytaryzmem i Totalitaryzmem 42, nr 1, 2020

(C) for this edition by CNS 
gowskiego ratusza), a jako detal architektoniczny wykorzystywany jest na całym świecie. W tych wypadkach nie można jednak mówić o jakichkolwiek nawiązaniach do ideologii faszystowskiej.

Natomiast w wypadku ideologii komunistycznej istnieje pewne przyzwolenie społeczne na posługiwanie się określonymi symbolami, które stały się elementami popkultury, na przykład czerwonej gwiazdy, sierpa i młota czy podobizny Che Guevary.

Wątpliwości i problemy mogą się natomiast pojawić w wypadku symboli i znaków nawiązujących pośrednio do systemów totalitarnych i związanych przede wszystkim z ruchami neonazistowskimi, na przykład liczb $18^{32}, 28^{33}, 88^{34}$, $19 / 8^{35}, 1919^{36}$ czy skrótów B\&H ${ }^{37}$ oraz WAP ${ }^{38}$. Kwestie te także były przedmiotem rozstrzygnięcia sądowego. Jak zauważył Sąd Apelacyjny w Warszawie,

publiczne prezentowanie także takich symboli, które nie są powszechnie znane, a tym samym identyfikowane $\mathrm{z}$ faszyzmem [...] także stanowi propagowanie go, skoro taka forma przekazu, nawet jeżeli przez część odbiorców zostanie zignorowana z powodu jej niezrozumienia, u innych spowoduje zaciekawienie, a przez to chęć ustalenia treści, która z niego wynika - a to stanowi formę propagowania ${ }^{39}$.

Natomiast w sposób całkowicie indywidualny należy oceniać używanie w przestrzeni publicznej symboli starszych aniżeli totalitarne ideologie i jedynie adaptowane przez ruchy neototalitarne, na przykład krzyż celtycki, krzyż słoneczny, runy czy grecki meandros. Rozstrzygający będzie bowiem kontekst, w jakim te symbole będą używane. Trudno bowiem będzie mówić o propagowaniu ustroju totalitarnego w wypadku działalności grup rekonstrukcyjnych przedstawiających na przykład życie Słowian czy wikingów albo w wypadku obecności greckiego meandrosa na wystawach dotyczących kultury lub sztuki starożytnej Grecji. Natomiast z całą pewnością pojawienie się tego typu symboli (tak jak pęku rózg liktorskich) obok swastyki ${ }^{40}$ na manifestacjach grup neonazistowskich lub neofaszystowskich bądź gdy towarzyszy im wznoszenie haseł rasistowskich, będzie miało charakter propagowania ustroju totalitarnego w rozumieniu art. 256 k.k.

32 Pierwsza i ósma litera alfabetu, czyli „A” i „H”, które razem tworzą inicjały Adolfa Hitlera.

33 Druga i ósma litera alfabetu, czyli „B” i „H”, które razem tworzą skrót nazwy neonazistowskiego ruchu Blood and Honour.

34 Podwójna ósma litera alfabetu to skrót od nazistowskiego pozdrowienia „Heil Hitler”.

35 Dziewiętnasta i ósma litera alfabetu, czyli „S” i „H”, które razem tworzą „Sieg heil”.

36 Podwójna liczba „19” (czyli litera „S” w alfabecie), czyli skrót „SS”. To także data powstania włoskiego manifestu faszystowskiego.

37 Skrót od „Blood and Honour”.

38 Skrót od ,White Aryan Power".

39 Wyrok SA w Warszawie - II Wydział Karny z dnia 30 maja 2018 roku.

$40 \mathrm{~W}$ ramach ciekawostki warto zauważyć, że w herbie szlacheckiego rodu Boreyko znajduje się lewostronna swastyka czerwona, której słup pionowy jest dwa razy złamany na końcach, umieszczona na srebrnym polu. Ma ona jednak korzenie sięgające jeszcze pogańskich czasów Rusi Kijowskiej.

Studia nad Autorytaryzmem i Totalitaryzmem 42, nr 1, 2020

(C) for this edition by CNS 
Polskie sądy rozpoznają taką symbolikę w kontekście karnoprawnym. Sąd Okręgowy w Siedlcach w wyroku z 2017 roku za przejaw propagowania ustroju faszystowskiego uznał umieszczenie $\mathrm{w}$ internecie obrazka zaopatrzonego w charakterystyczny symbol „SS”41. Oskarżony umieścił na portalu społecznościowym kopię nazistowskiego plakatu zachęcającego do wstępowania do 12 Dywizji Pancernej SS „Hitlerjugend” (na plakacie jest dwóch młodych mężczyzn, symbol „SS” oraz hasło „Komm mit uns”42). Dzieje się tak też gdy oskarżeni posłują się mniej wyrazistymi symbolami. W innym wyroku, oceniając zebrany materiał dowodowy, sąd wskazał, że zabezpieczone nalepki zawierały

typowe dla języka neonazistowskiego techniki kamuflażu treści kontrowersyjnych z moralnego i prawnego punktu widzenia oraz gry komunikacyjne oparte na zaprogramowanej niejasności przekazu, którego sens ma zostać bez trudu rozszyfrowany przez odbiorę. Zawarte zaś w nich treści słowne i graficzne propagowały totalitarny ustrój państwa oraz wzywały do nienawiści na tle różnic narodowościowych, etnicznych, rasowych i wyznaniowych ${ }^{43}$.

\section{Publiczne nawoływanie do nienawiści na tle różnic narodowościowych, etnicznych, rasowych, wyznaniowych albo ze względu na bezwyznaniowość}

W wypadku tego aspektu rozpowszechniania mowy nienawiści należy się skupić na rozumieniu zwrotu „nawoływanie do nienawiści”, gdyż pozostałe terminy są wystarczająco dookreślone w literaturze naukowej i nie wymagają szczegółowej analizy. Wskazać można kilka orzeczeń, które definiowały ten termin. W postanowieniu z 2007 roku Sąd Najwyższy wskazał, że nawoływanie do nienawiści

z powodów wymienionych w art. 256 k.k. — w tym na tle różnic narodowościowych — sprowadza się do tego typu wypowiedzi, które wzbudzają uczucia silnej niechęci, złości, braku akceptacji, wręcz wrogości do poszczególnych osób lub całych grup społecznych czy wyznaniowych bądź też z uwagi na formę wypowiedzi podtrzymują i nasilają takie negatywne nastawienia i podkreślają tym samym uprzywilejowanie, wyższość określonego narodu, grupy etnicznej, rasy lub wyznania ${ }^{44}$.

Takie stanowisko też przyjął Sąd Apelacyjny w Katowicach w wyroku z 2013 roku, w którym podkreślił, że

41 Sąd Okręgowy w Siedlcach tym wyrokiem uchylił wyrok sądu rejonowego, który oskarżonego uniewinnił od popełnienia zarzucanego mu czynu.

42 Komm mit uns — „Chodź z nami”.

43 Wyrok SA we Wrocławiu z dnia 7 marca 2013 roku, sygn. II AKa 398/12, https://sip. lex.pl/orzeczenia-i-pisma-urzedowe/orzeczenia-sadow/ii-aka-398-12-pojecie-zorganizowania-z-art-258-1-k-k-a-521416564 (dostęp: 20.05.2020).

44 Postanowienie SN z dnia 5 lutego 2007 roku, sygn. IV KK 406/06, OSNwSK 2007/1/367, LEX nr 245307.

Studia nad Autorytaryzmem i Totalitaryzmem 42, nr 1, 2020

(C) for this edition by CNS 
Pojęcie nawoływania do nienawiści na tle różnic rasowych traktować należy jako publiczne wzywanie (nawoływanie) innych osób do odczuwania i utrwalenia negatywnych emocji, niechęci oraz wrogości wobec przedstawicieli odmiennej rasy ${ }^{45}$.

Wskazane pojmowanie Sąd Najwyższy znacząco uściślił w postanowieniu z 2011 roku, w którym podkreślił, że nawoływanie do nienawiści oznacza chęć

wzbudzenia u osób trzecich najsilniejszej negatywnej emocji (zbliżonej do wrogości) do określonej narodowości, grupy etnicznej czy rasy. Nie chodzi tu w żadnym razie o wywoływanie uczuć dezaprobaty, antypatii, uprzedzenia, niechęci ${ }^{46}$.

Rozważania Sądu Najwyższego należy uzupełnić o stanowisko Trybunału Konstytucyjnego, jakie TK zajął, stwierdzając zgodność z Konstytucją zwrotu „nawołuje do nienawiści” w wyroku z 2014 roku. Po pierwsze, biorąc pod uwagę dotychczasowe orzecznictwo Sądu Najwyższego, zauważono, że wypracowuje się dopiero jego rozumienie. Po drugie, Trybunał Konstytucyjny zwrócił uwagę na przywołane przez Sąd Najwyższy dwie reguły konieczne przy interpretowaniu, czym jest nawoływanie do nienawiści w rozumieniu art. 256 k.k., to jest zakaz wykładni rozszerzającej oraz konieczność uwzględniania powszechnego znaczenia słów ${ }^{47}$.

Analizując wskazane kwestie, Trybunał zauważył, że o ile rzeczywiście omawiany zwrot jest niedookreślony i nieostry, o tyle „zostaje uściślony dzięki kontekstowi normatywnemu, w którym występuje". Po pierwsze, przestępstwem jest więc tylko nawoływanie do nienawiści, które ma charakter publiczny. Po drugie, można je popełnić jedynie w wyniku działania. Po trzecie zaś, dotyczy wyłącznie nawoływania z powodu zamkniętego katalogu pobudek: na tle różnic narodowościowych, etnicznych, rasowych, wyznaniowych albo ze względu na bezwyznaniowość. Po czwarte, przestępstwo można popełnić tylko z zamiarem bezpośrednim ${ }^{48}$.

Za niezwykle istotne do zdefiniowania mowy nienawiści należy uznać wskazanie Trybunału odnośnie do zamiaru sprawcy. Według TK musi on chcieć oddziaływać na psychikę innych osób, aby wzbudzić w nich najsilniejszą negatywną emocję (nienawiść). Samo publiczne ujawnienie własnych poglądów, przykładowo niechęci czy wrogości do pewnej grupy społecznej, nawet jeżeli są one w odczuciu społecznym nieakceptowalne czy kontrowersyjne, nie może zostać uznane za nawoływanie do nienawiści. Postawa rozpowszechniającego dane poglądy musi być bowiem równoznaczna z wzywaniem innych do „nienawiści,

45 Wyrok SA w Katowicach z dnia 24 września 2013 roku, sygn. II AKa 301/13, LEX nr 1422288.

46 Postanowienie SN z dnia 1 września 2011 roku, sygn. V KK 98/11, LEX nr 950444.

47 Wyrok TK z 25 lutego 2014 roku, sygn. SK 65/12, 13/2/A/2014, https://ipo.trybunal.gov. pl/ipo/downloadOrzeczenieDoc?dok=45868 (dostęp: 20.05.2020).

48 Ibidem.

Studia nad Autorytaryzmem i Totalitaryzmem 42, nr 1, 2020

(C) for this edition by CNS 
czyli najsilniejszej negatywnej emocji (zbliżonej do wrogości)"49. Tytułem uzupełnienia warto zwrócić uwagę na definiowanie zwrotu „nawołuje do nienawiści” w doktrynie prawa karnego ${ }^{50}$.

Trzeba przede wszystkim wskazać na przykłady zachowań, których sądy nie uznały za rozpowszechnianie mowy nienawiści. Za działanie niewypełniające znamion czynu zabronionego uznano (sąd rejonowy, okręgowy i Sąd Najwyższy) czyn polegający na publicznym (w trakcie legalnej manifestacji) prezentowaniu hasła „Wyzwolimy Polskę od euro-zdrajców, Żydów, masonów i rządowej mafii”. Sąd I instancji uznał, że

oskarżony swoim publicznym zachowaniem manifestował jedynie osobiste poglądy, zapowiedzi lub deklaracje działania, które nie mają w swej treści negatywnych skojarzeń na tle różnic narodowościowych i nie są nacechowane nienawiścią wobec grupy narodowościowej.

Natomiast sąd II instancji podkreślił, że „na tle całokształtu okoliczności sprawy - przebiegu manifestacji, postawy oskarżonego w czasie manifestacji przy braku jakichkolwiek dodatkowych - poza treścią niesionego transparentu - wypowiedzi, gestów" ${ }^{51}$ nie można mu przypisać zamiaru nawoływania do nienawiści. Oba sądy podkreśliły tryb orzekający użytego czasownika (,wyzwolimy"), uznając, że aby mówić o nawoływaniu, musiałby on mieć formę trybu rozkazującego („wyzwólmy”). Z tym stanowiskiem zgodził się Sąd Najwyższy, który ocenił, że w tym konkretnym wypadku rozpowszechniający wskazane hasło

49 Ibidem.

50 1. „[N]akłanianie (podżeganie), skierowane do większej, bliżej nieokreślonej liczby osób. Celem przestępnego działania jest sianie nienawiści, przez którą rozumie się wrogość prowadzącą do konfliktów między grupami ludności na tle wyżej wymienionych różnic" (A. Marek, Kodeks karny. Komentarz, Warszawa 2010, s. 553); 2. „zachowanie polegające na sianiu nienawiści, czyli uczucia silnej niechęci, wrogości do powyższych osób" (E. Pływaczewski, A. Sakowicz, [w:] Kodeks karny. Część szczególna, t. 2. Komentarz do artykułów 222-316, red. A. Wąsek, R. Zawłocki, Warszawa 2010, s. 489); 3. „sianie nienawiści, czyli silnej niechęci, wrogości do innej osoby czy osób. Nawoływanie to namawianie, zachęcanie, skłanianie, podburzanie, podżeganie, bez względu na to, czy nawoływanie odniosło skutek" (M. Mozgawa, [w:] Kodeks karny. Komentarz, red. M. Mozgawa, Warszawa 2013, s. 594); 4. „wzbudzanie niechęci, złości, braku akceptacji, a nawet uczucia wściekłości z tych powodów do poszczególnych osób lub całych grup społecznych albo też podtrzymywanie i nasilanie tego nastawienia. [...] Dla realizacji znamienia »nawoływanie do nienawiści« wystarczy, że sprawca, nawołując, zmierza do pojawienia się uczucia wrogości wobec określonych w przepisie osób. Takie uczucie zamierza wzbudzić. Nawoływanie musi zatem zawierać takie treści, które są w stanie wzbudzać nienawiść, to jest wrogość, silną niechęć do kogoś" (Z. Ćwiąkalski, [w:] Kodeks karny. Część szczególna. Komentarz, t. 2. Komentarz do art. 117-277 k.k., red. A. Zoll, Warszawa 2013, s. 1382-1383); 5. „Zachowanie polegające na sianiu nienawiści, czyli uczuciu silnej niechęci, wrogości do osób z uwagi na ich przynależność do określonych grup narodowościowych, etnicznych, rasowych, wyznaniowych czy bezwyznaniowych" (A. Herzog, Kodeks karny. Komentarz, red. R.A. Stefański, Warszawa 2013, teza 11).

51 Postanowienie SN z dnia 5 lutego 2007 roku.

Studia nad Autorytaryzmem i Totalitaryzmem 42, nr 1, 2020

(C) for this edition by CNS 
w ten sposób „dał wyraz swoim osobistym poglądom” i „wyrażał wyłącznie swój osobisty pogląd i stosunek do wymienionego w nim narodu"52.

Sąd Najwyższy — za sądem II instancji — przypomniał, że wolność słowa dotyczy także opinii, które są

z punktu widzenia zasad współżycia społecznego oraz sposobu korzystania z praw i wolności naganne. W sferze opinii, przekonań religijnych należy unikać wyrażeń, które niepotrzebnie obrażają innych i na pewno nie przyczyniają się w żaden sposób do debaty publicznej zdolnej zapewnić realny postęp w rozwiązywaniu problemów. Nie oznacza to jednak, że każde powszechnie nieakceptowane wyrażanie swoich poglądów, odczuć, stosunku do innych należy penalizować 53 .

W tym wypadku pierwszeństwo dano zatem swobodzie wypowiedzi, także tych, które mogą w swej treści zawierać określenie jakiejś grupy w sposób negatywny. W omawianym przypadku chodzi o Żydów i masonów, trudno bowiem uznać za pozytywne umieszczenie ich w jednym rzędzie z „euro-zdrajcami” i ,rządową mafią".

Propagowanie osobistych poglądów może także przybierać formę prowadzenia działalności gospodarczej polegającej na sprzedaży ubrań z widniejącymi na nich określonymi hasłami. Tego typu kwestie rozstrzygał Sąd Rejonowy w Częstochowie w 2016 roku $^{54}$. Oskarżony sprzedawał bluzy i koszulki z między innymi krzyżem celtyckim i napisem „Jestem dumny z tego, że jestem Biały, być może niedługo tylko to mi pozostanie", twarzą człowieka zasłoniętą chustą, krzyżem celtyckim i napisem „White Patriots” albo napisem „Narodowe Siły Zbrojne". Spośród kilkudziesięciu koszulek poddanych analizie przez biegłego jedynie jedna została przez niego uznana za bezpośrednie publiczne propagowanie ustroju

52 Ibidem.

53 Ibidem. W tym kontekście zazwyczaj w doktrynie prawa karnego przypomina się wyrok ETPCz Handyside przeciwko Wielkiej Brytanii. Pisząc o wypowiedziach o treści nieakceptowanej przez większości społeczeństwa, warto jednak sięgnąć także do doświadczeń amerykańskich. Przytoczyć należy chociażby sprawę Snyder v. Phelbs - 3 marca 2006 roku żołnierz piechoty morskiej Matthew A. Snyder zginął z wypadku samochodowym w Iraku; 10 marca członkowie Westboro Baptist Church (WBC) pikietowali w czasie jego pogrzebu w Westminster, Maryland, tak jak w czasie tysiąca innych pogrzebów, protestując przeciwko - ich zdaniem - zwiększającej się tolerancji wobec homoseksualistów w Ameryce. The Westboro Baptist Church (WBC) jest amerykańskim Kościołem protestanckim, który znany jest ze swoich skrajnych poglądów i wypowiedzi, skierowanych zwłaszcza wobec gejów i lesbijek. Albert Snyder, ojciec Matthew Snydera, pozwał Freda Phelpsa, Westboro Baptist Church i dwie jego córki Rebekah Phelps-Davis i Shirley Phelps-Roper za zniewagę, naruszenie prywatności i celowe wywoływanie niepokoju emocjonalnego. W 2010 roku sprawa trafiła do Sądu Najwyższego. SN stwierdził, iż wypowiedzi w miejscach publicznych (chodnik) związane z kwestiami ważnymi dla sfery publicznej nie mogą być zakazane czy nawet uznane za przestępstwo, nawet jeśli uznawane są za „skandaliczne” (outrageous). Zob. Snyder v. Phelps, 562 U.S. 443 (2011), https://supreme.justia.com/cases/federal/us/562/443/ (dostęp: 30.03.2019).

54 Wyrok SR w Częstochowie z dnia 20 stycznia 2016 roku, sygn. IV K 24/15, http://orzeczenia.czestochowa.sr.gov.pl/content/\$N/151510050002006_IV_K_000024_2015_Uz_2016-01-29_001 (dostęp: 20.05.2020).

Studia nad Autorytaryzmem i Totalitaryzmem 42, nr 1, 2020

C for this edition by CNS 
faszystowskiego (przedstawiająca mężczyzn w uniformach przypominających mundur żołnierza „SS”). Jak jednak skonstatował sąd w uzasadnieniu wyroku, biegły nie był w stanie ,stwierdzić, na ile potencjalni odbiorcy takiego wizerunku ulegną tym napisom, treściom i rysunkom, a zatem na ile takie działanie poprzez rozpowszechnianie tego wizerunku będzie miało wpływ na zachowania innych ludzi" ${ }^{55}$. Natomiast w odniesieniu do użycia krzyża celtyckiego sąd słusznie zauważył, że w Polsce „nie jest symbolem zakazanym, ale już w Niemczech jest, albowiem jest on kojarzony z działalnością neofaszystów" $" 56$.

Trudno jednak zrozumieć tok rozumowania sądu, gdyż przestępstwa propagowania ustroju i nawoływania do nienawiści są przestępstwami formalnymi i mają charakter bezskutkowy. Oznacza to, że do zaistnienia przestępstwa zarówno propagowanie, jak i nawoływanie nie muszą wywołać żadnych skutków, choćby w sferze psychiki (zmiana emocji) odbiorców wypowiedzi. Ewentualne efekty propagowania i nawoływania nie należą do zbioru znamion tego przestępstwa. Jak zauważył Sąd Apelacyjny w Katowicach,

pojęcie nawoływania do nienawiści na tle różnic rasowych traktować należy jako publiczne wzywanie (nawoływanie) innych osób do odczuwania i utrwalania negatywnych emocji, niechęci oraz wrogości wobec przedstawicieli odmiennej rasy, przy czym dla realizacji występku określonego w art. $256 \S 1$ k.k. nie jest konieczny skutek w postaci przekonania przez sprawcę innych odbiorców do prezentowanych przez siebie poglądów, chociaż tym motywowane winno być jego zachowanie w inkryminowanym miejscu i czasie ${ }^{57}$.

Sąd dał wiarę wyjaśnieniom oskarżonego, który podkreślał, że jego zamiarem nie było nawoływanie od nienawiści, lecz jedynie manifestowanie swoich przekonań, które sam określił jako narodowe i nacjonalistyczne (tego typu poglądy zostały określone w prasie jako „radykalny patriotyzm”58). O ile można zrozumieć tok rozumowania sądu w odniesieniu do większości sprzedawanych przedmiotów, o tyle krytycznie należy ocenić uznanie, że grafika przedstawiająca mężczyzn w mundurach przypominających uniform żołnierza „SS” nie stanowi odwołania do ideologii nazistowskiej i sprzedaż tego typu przedmiotów nie jest nawoływaniem do nienawiści.

Z kolei w 2013 roku Sąd Apelacyjny w Katowicach uznał, że zwrócenie się do osoby trzeciej w miejscu publicznym słowami „czarnuch, czarna świnia” nie wypełnia wszystkich znamion przestępstwa z art. 256 k.k., gdyż „nie było umotywowane chęcią wzbudzenia [...] wrogości na tle różnic rasowych, a nadto przekazywany przez oskarżonego komunikat trudno uznać za taki, który mógłby wzbudzić w odbiorcach negatywne emocje" w postaci nienawiści. Natomiast

55 Ibidem.

56 Ibidem.

57 Wyrok SA w Katowicach z dnia 24 września 2013 roku.

58 M. Mamoń, Prokuratura: To faszyzm. Sąd: Nie, to radykalny patriotyzm, http://czestochowa. wyborcza.pl/czestochowa/1,89625,19508506,prokuratura-to-faszyzm-sad-nie-to-radykalnypatriotyzm.html (dostęp: 10.01.2019).

Studia nad Autorytaryzmem i Totalitaryzmem 42, nr 1, 2020

(C) for this edition by CNS 
była to wypowiedź, która znieważała obywatela, do którego była kierowana, „obrażając go i naruszając jego prawo do dobrego imienia z powodu przynależności rasowej" 59 . Sąd uznał zatem, że w tym wypadku nie mamy do czynienia z mową nienawiści w wąskim znaczeniu, lecz jedynie z językiem pogardy, który mógłby być ścigany na mocy innych przepisów prawa karnego (art. 216 k.k., penalizujacy przestępstwo zniewagi).

Odróżnienia manifestowania osobistych poglądów od nawoływania do nienawiści dotyczyło także orzeczenie Sądu Rejonowego w Gdańsku z 21 lutego 2017 roku. Oskarżony trafił przed sąd w efekcie swojego wystąpienia przed Konsulatem Honorowym Republiki Litwskiej, które opublikowano potem w sieci. $\mathrm{W}$ czasie swej przemowy, jak to ujęto w akcie oskarżenia,

publicznie nawoływał do nienawiści na tle różnic narodowościowych wobec Republiki Litewskiej oraz jej obywateli poprzez wypowiadanie w przestrzeni publicznej m.in. następujących haseł: tzw. Republika Litewska, beneficjenci agresji na Polskę, umożliwiali bolszewikom pochód na [...] post-szaulistowski reżim, nie zamierzając oddać prawowitego terytorium, uzurpujący historyczną nazwę Litwa, polskie W., spadkobiercy zbrodni w P., ziemie tymczasowo wchodzące w skład Republiki Litewskiej, polska armia bez trudu zajęłaby całe terytorium tzw. Republiki Litewskiej60.

Sąd uznał, że wygłoszone przemówienie „odzwierciedlało poglądy historyczne i polityczne oskarżonego". Ponadto zwrócił uwagę, że miało ono miejsce w czasie trwającej kampanii wyborczej w 2015 roku, oskarżony zaś występował w charakterze kandydata na posła do Sejmu RP. Sąd wskazał na zeznania oskarżonego, w których podnosił, że celem jego wystąpienia nie było nawoływanie do nienawiści narodowościowych, lecz

poruszenie w debacie publicznej kwestii losu Polaków żyjących na Wileńszczyźnie. Oskarżony podkreślał, że jego wystąpienie było motywowane tym, że celem wystąpienia było poruszenie w przestrzeni publicznej kwestii prześladowań mniejszości polskiej na Litwie z racji tego, „,że jest to temat przez media bardzo często pomijany"61

Ponadto sąd zwrócił uwagę na zeznania pracownika konsulatu, który wskazał, że treść wystąpienia oskarżonego nie odbiegała od wielu podobnych, tym bardziej pojawiających się podczas kampanii wyborczej, zawierała co najwyżej sformułowania mogące zostać uznane za obraźliwe, nie była zaś przejawem nawoływania do nienawiści na tle różnic narodowościowych. Podkreślono także, że na wystąpienie oskarżonego nie zwrócił uwagi żaden z przechodniów. Sąd podnosił, że należy badać całość wypowiedzi oskarżonego, prokuratura zaś wyrwała z kontekstu poszczególne zwroty. Zdaniem sądu wypowiedzi oskarżonego

59 Wyrok SA w Katowicach z dnia 24 września 2013 roku.

60 Wyrok SR w Gdańsku (Gdańsk-Południe) Wydział II Karny z dnia 21 lipca 2017 roku, sygn. II K 528/16, https://sip.lex.pl/orzeczenia-i-pisma-urzedowe/orzeczenia-sadow/ii-k-240-17-wyrok-sadu-rejonowego-gdansk-poludnie-w-522818186 (dostęp: 20.05.2020).

61 Ibidem.

Studia nad Autorytaryzmem i Totalitaryzmem 42, nr 1, 2020

(C) for this edition by CNS 
zawarte na filmie nagranym przed budynkiem Konsulatu Honorowego Republiki Litewskiej nie można oceniać w oderwaniu od okoliczności, w jakich powstały, a przede wszystkim nie można rozpatrywać poszczególnych, wyjętych z kontekstu — jak opisano w zarzucie aktu oskarżenia — wypowiedzi ${ }^{62}$.

W innej sprawie Sąd Apelacyjny we Wrocławiu podkreślił, że w demokratycznym państwie prawa „nie jest karalne identyfikowanie się z jakąkolwiek subkulturą, w tym ze środowiskiem neonazistowskim, skinheadowskim lub grupami kibiców piłkarskich”. Niekaralne także jest „posiadanie poglądów akceptujących totalitarny ustrój państwa, a nawet nienawiść narodowościową, rasową, wyznaniową, ze względu na odmienność poglądów politycznych lub ze względu na przynależność do tzw. mniejszości seksualnych i innych". Problemem jest natomiast sytuacja, gdy poglądy te są wyrażane publicznie w warunkach art. 256 k.k. i art. 257 k.k. Dopiero w takich okolicznościach ustawodawca uznał je za „groźne społecznie"63.

W wypadku nawoływania do nienawiści pojawia się wspomniany już problem braku symetrii między ściganiem ideologii faszystowskiej i nazistowskiej z jednej strony, a komunistycznej z drugiej. Dwukrotnie zwrócił na to uwagę Trybunał Konstytucyjny. W 2011 roku podkreślił, że ustawodawca penalizuje działania zmierzające do propagowania ustroju zarówno skrajnie prawicowego (faszyzmu i nazizmu), jak i skrajnie lewicowego (komunizmu). Natomiast w odniesieniu do ,ideologicznych fundamentów” tych systemów ściganie ograniczono wyłącznie do faszystowskiego i nazistowskiej nienawiści z powodów narodowościowych, etnicznych i rasowych. To pominięcie ,szerzenia nienawiści na tle różnic klasowych" Trybunał Konstytucyjny uznał za skutek regulacji międzynarodowej zawartej w Międzynarodowych paktach praw obywatelskich i politycznych, w których w art. 20 ust. 2 określono, że popieranie w jakikolwiek sposób nienawiści narodowej, rasowej lub religijnej, stanowiące podżeganie do dyskryminacji, wrogości lub gwałtu, powinno być ustawowo zakazane ${ }^{64}$. Kontynuując ten wątek, w 2014 roku Trybunał Konstytucyjny wskazał, że wspólnota międzynarodowa ,zignorowała jeden z kluczowych aspektów przedmiotowych zbrodni ludobójstwa - wyniszczenie grupy oznaczonej jako wroga czy pasożytnicza klasa ekonomiczno-społeczna" ${ }^{65}$. Wydaje się jednak jasne, że w trakcie zimnej wojny niemożliwe było włączenie tej przesłanki do przepisów prawa międzynarodowego z uwagi na siłę i znaczenie Związku Radzieckiego.

62 Ibidem.

63 Wyrok SA we Wrocławiu z dnia 7 marca 2013 roku.

64 Międzynarodowy pakt praw obywatelskich i politycznych uchwalony przez Zgromadzenie Ogólne Narodów Zjednoczonych w dniu 16 grudnia 1966 roku w Nowym Jorku (Dz.U. z 1994 r. Nr 23, poz. 80).

65 Wyrok TK z dnia 25 lutego 2014 roku, sygn. SK 65/12, 13/2/A/2014, https://ipo.trybunal. gov.pl/ipo/downloadOrzeczenieDoc?dok=45868 (dostęp: 20.50.2020).

Studia nad Autorytaryzmem i Totalitaryzmem 42, nr 1, 2020

(C) for this edition by CNS 
Mowa nienawiści w wąskim zakresie może być także rozpowszechniania za pomocą muzyki. Za czyn będący jednocześnie propagowaniem totalitarnego ustroju państwa oraz nawoływaniem do nienawiści sąd uznał wykonywanie na koncertach utworów „z motywami charakterystycznymi dla muzyki identyfikowanej z neonazizmem". W przekonaniu sądu takimi elementami są między innymi

wezwania do [...] odrzucenia demokracji i politycznej poprawności, podpierane demagogicznym hasłem o wyższości białej rasy. [...] symbole nazistowskie III Rzeszy Niemieckiej i hitleryzmu [...], charakterystyczne symbole współczesnego neonazizmu [...] i wezwania neonazistowskie: przepowiadające nadejście rewolucji i dokonanie zemsty na wrogu, wątki antychrześcijańskie — obcej wiary, żydowskiej religii ${ }^{66}$.

\section{Publiczne znieważenie grupy ludności}

\section{albo poszczególnej osoby z powodu jej przynależności narodowej, etnicznej, rasowej, wyznaniowej albo z powodu jej bezwyznaniowości}

W wypadku terminu ,znieważać” zarówno doktryna prawa karnego, jak i orzecznictwo ma ugruntowane kierunki interpretacji. Wynika to z faktu, że wspomniany czasownik występuje nie tylko w omawianym przepisie, ale i w art. 216 k.k. (zniewaga). W wypadku art. 257 k.k. termin jest dookreślony tym, że znieważenie musi nastąpić w powodu przynależności do grupy rasowej, narodowościowej, etnicznej, religijnej albo ze względu na bezwyznaniowość.

Jak podkreśla się w wyrokach w sprawach karnych, interpretacja sformułowania „znieważa” jest taka sama jak w wypadku art. 216 k.k., a zatem chodzi tu o znieważenie osoby wypowiedzią skutkującą naruszeniem czci i godności. Wypowiedź musi mieć obiektywnie charakter znieważający, a nie tylko być taką w subiektywnym przekonaniu ofiary. Należy też uwzględnić lokalne znaczenie poszczególnych słów, które mogą mieć w danej społeczności charakter obraźliwy. Zamiar sprawcy, czy to w postaci znieważenia, czy też naruszenia nietykalności cielesnej, musi być ściśle związany z powodem, którym jest przynależność narodowa, etniczna, rasowa, wyznaniowa lub bezwyznaniowość ofiary. Działanie sprawcy z innych powodów nie pozwala na kwalifikację prawną z art. 257 k.k. ${ }^{67}$

$\mathrm{Za}$ znieważające uznano przykładowo wlepkę ${ }^{68}$ zawierającą przekreślony wizerunek brodatego mężczyzny, przedstawiającego osobę narodowości romskiej, z podpisem o treści: „wolna od cygaństwa”. Sąd uznał, że taki obrazek

66 Wyrok SA we Wrocławiu z dnia 7 marca 2013 roku.

67 Ibidem.

68 Vlepka (wlepka) — niewielka naklejka umieszczana bez zezwolenia w przestrzeni publicznej (na przykład na szybach autobusów lub tramwajów), zawierająca rysunek (zdjęcie) lub tekst.

Studia nad Autorytaryzmem i Totalitaryzmem 42, nr 1, 2020

C for this edition by CNS 
jednoznacznie sugeruje, że wszyscy Romowie „to bez wyjątków oszuści (cygaństwo to tyle co hochsztaplerstwo, oszustwo)", co należy uznać za treści obiektywnie znieważające ${ }^{69}$.

Podobnie można wskazać przykłady wypowiedzi, które zostały uznane przez sądy polskie za znieważające w rozumieniu art. 257 k.k., a co za tym idzie należy je zaliczyć do przykładów mowy nienawiści w wąskim znaczeniu. W wyroku z 30 czerwca 2016 roku Sąd Okręgowy w Białymstoku wskazał szereg wypowiedzi, które stanowią omawiane znieważenie - oskarżony umieszczał na internetowych forach komentarze dotyczące osób narodowości czeczeńskiej ${ }^{70}$. Przez pryzmat uchodźców (muzułmanie), którzy według autora komentarza w perspektywie mieliby trafić do Polski, padają określenia „śniade cwaniaki” i „leniwe dranie". Już sam ich wydźwięk w potocznym języku jawi się jako jednoznacznie negatywny i pejoratywny. Tyle że autor wpisu niejako dodatkowo sugeruje, iż poza pobieraniem zasiłków owe ,śniade cwaniaki”, niezainteresowane poszukiwaniem pracy, będą niejako z zasady sprawcami czynów przestępczych (,będą się panoszyć, dorabiając kradzieżami i rozbojami”). Takie przedstawianie wizji pobytu Czeczenów - narodu według autora komentarza znacznie agresywniejszego od innych uchodźców (Albańczycy, Marokańczycy, Turcy) - dodatkowo wzmocnione twierdzeniem, że jedyną reakcją na taką ich postawę może być ucieczka z kraju, umożliwiająca wychowywanie dzieci bez strachu, to z pewnością znacznie wykraczające poza subiektywną ocenę autora komentarza stanowisko przypisujące innej narodowości negatywne i obraźliwe cechy, mające na celu spotęgowanie nienawiści i sprzeciwu wobec zjawiska napływu narodu czeczeńskiego do naszego $\mathrm{kraju}^{71}$.

W ocenie sądu okręgowego bez wątpienia przytoczone w omawianym tekście określenie „k. leniuchy” niesie z sobą zabarwienie emocjonalne, obiektywnie pejoratywne. Synonimami określenia „leniuch, leń” są takie określenia, jak: „nierób, próżniak, obibok". Przez pryzmat znamion przestępstwa z art. 257 k.k. już samo jego użycie dotyka godności człowieka, obraża go oraz narusza jego cześć. Dodatkowo w przedmiotowym wpisie wyraźnie pada ono w kontekście narodu

69 Sąd jednak wskazał, że brakuje jednoznacznych i przekonujących dowodów, że oskarżeni adresowali swoje przesłanie do osób narodowości romskiej. Stojąc na stanowisku, że przestępstwo z art. 257 k.k. można popełnić wyłącznie umyślnie w zamiarze bezpośrednim, sąd stwierdził, że nie można im przypisać przestępstwa z art. 257 k.k. Wskazał przy tym, że „nie w każdym wypadku przestępstwo z art. $256 \S 1$ k.k. pociąga za sobą wypełnienie dyspozycji art. 257 k.k. Nawoływanie do nienawiści [...] wcale nie musi się łączyć ze znieważeniem wspomnianych grup ludności albo poszczególnych osób. Przecież nawoływanie do nienawiści wypowiadane (prezentowane) jest z reguły nie do przedstawicieli dyskryminowanych grup, lecz do tych, którzy by mieli je dyskryminować" - wyrok SA we Wrocławiu z dnia 7 marca 2013 roku.

70 Wyrok SA w Białymstoku VIII Wydział Karny Odwoławczy z dnia 30 czerwca 2016 roku, sygn. VIII Ka 157/16, http://orzeczenia.bialystok.so.gov.pl/content/\$N/150505000004006_VIII_Ka 000157 2016_Uz_2016-06-30_001 (dostęp: 20.05.2020).

71 Ibidem.

Studia nad Autorytaryzmem i Totalitaryzmem 42, nr 1, 2020

(C) for this edition by CNS 
czeczeńskiego, który według autora — w przeciwieństwie do Polaków — jest gotów przeprowadzać zamachy w imię wiary oraz mordować niewinnych ${ }^{72}$. Jak zauważył sąd, określenia typu ,ścierwo pasożytnicze”, zwłaszcza w obliczu pierwotnego tytułu wątku dyskusji, wskazują, że komentarze oskarżonego dotyczą wprost Czeczenów, a użyte w nich przez niego słowa w dyskursie publicznym mają jednoznacznie pejoratywny charakter, a poza tym, że są obelżywe w rozumieniu przepisu art. 257 k.k., to w sposób jednoznaczny dyskredytują mniejszość czeczeńską jako naród ${ }^{73}$.

\section{Podsumowanie}

Podejmując próbę zdefiniowania mowy nienawiści w języku prawniczym sfery karnoprawnej, trzeba mieć na uwadze reguły interpretacyjne, które wskazał Sąd Najwyższy w swoim postanowieniu z 2011 roku. Po pierwsze, bezwzględny zakaz stosowania wykładni rozszerzającej, jeśli prowadziłoby to do rozszerzenia odpowiedzialności karnej oskarżonego (ze względu na zasadę nullum crimen, nulla poena sine lege). Po drugie, względny zakaz nadawania zwrotom prawnym znaczenia odmiennego od potocznego, z wyjątkiem sytuacji, gdy przemawiają za tym ważne racje. Oznacza to zatem, że definiowanie mowy nienawiści w języku prawniczym powinno mieć na celu jak najdokładniejsze określenie, czym to zjawisko jest. W kontekście karnoprawnym wydaje się, że wskazane wymogi spełnia odwołanie się bezpośrednio do tekstu przepisów. Jednak oparcie się wyłącznie na art. 256 k.k., co można wysnuć z orzeczeń Trybunału Konstytucyjnego z 2011 i 2015 roku, wydaje się niewystarczające. Bez wątpienia bowiem także znieważanie $\mathrm{z}$ powodów wymienionych $\mathrm{w}$ art. 257 k.k. zawiera w sobie silny ładunek negatywnych emocji, zbliżonych do wrogości.

Zawarta w artykule analiza orzeczeń skłania do wysnucia kilku wniosków w charakterze podsumowania. Przede wszystkim mowa nienawiści jest w sferze sądowej pojmowana w sposób wąski, a w doktrynie prawa karnego nie ma większych sporów dotyczących samej istoty mowy nienawiści w znaczeniu wąskim. Orzecznictwo wypracowało określone rozumienie zastosowanych zwrotów, które składają się na definicję mowy nienawiści w tym znaczeniu. Sądy bardzo szczegółowo rozpatrują poszczególne sprawy i w sposób istotny ważą wartości wolności wypowiedzi i wartości chronionych przez art. 256 i 257 k.k. Pośrednie ślady określania, czym jest mowa nienawiści, można znaleźć w wyrokach dotyczących innych przepisów prawa karnego. Przykładowo jako przeciwieństwo rzeczowej krytyki mowę nienawiści określił Trybunał Konstytucyjny w wyroku z 2006 roku $^{74}$.

72 Ibidem.

73 Ibidem.

74 „Celowość karalności zniewagi na podstawie zarówno art. $216 \S 1$ k.k., jak i art. $226 \S 1$ k.k. uzasadniona jest potrzebą eliminacji z życia publicznego mowy nienawiści, zastępującej rzeStudia nad Autorytaryzmem i Totalitaryzmem 42, nr 1, 2020

(C) for this edition by CNS 
Problemem jest jednak to, czy w omawianych przypadkach należy uzupełnić katalog przesłanek o płeć, orientację seksualną, tożsamość płciową, niepełnosprawność i inne proponowane przez posłów w ostatnich latach, lub też o przynależność klasową, na co zwracały uwagę TK i SN. Automatycznie zmieniłoby to bowiem definicję mowy nienawiści w wąskim znaczeniu. Argumentem przemawiającym za takim podejściem jest to, że wskazywane cechy coraz częściej stają się powodem formułowania negatywnych opinii nacechowanych nienawiścią i nawołujących do dyskryminacji.

Zwolennicy wskazują, że walka z jednym i drugim zjawiskiem jest obowiązkiem państwa. Taka decyzji pociąga za sobą jednak od razu problem w postaci wskazania, które z grup winny być włączone pod ochronę omawianych przepisów (przykładowo czy tylko kobiety i osoby homoseksualne, czy też osoby starsze, chore i niepełnosprawne, a może także osoby o określonych przekonaniach politycznych?). Przeciwnicy rozszerzania zakresu penalizacji wskazują najczęściej na argument z ochrony wolności słowa. W kontekście polskiego systemu prawa karnego wydaje się, że równie istotnym (jeśli nie ważniejszym) argumentem może być odwołanie się do pewnej ciągłości normatywnej i wcześniejszych regulacji. Jak często wskazuje się zarówno w doktrynie prawa karnego, jak i orzecznictwie sądów, poprzednikami obecnych regulacji był art. 272 k.k. z 1969 roku ${ }^{75}$, który regulował nawoływanie do waśni narodowościowych, pochwałę faszyzmu i zniewagę ze względów narodowościowych - brakowało tam innych przesłanek. Oczywiście argument ten można odrzucić. Trudno zaś odrzucić argument o dyskryminacji tych grup, których nie objęłaby ochrona znowelizowanych przepisów.

Podstawowym problemem do rozstrzygnięcia jest coraz szersze pojmowanie mowy nienawiści. Także w sprawach karnych pojawiają się odwołania do mowy nienawiści w sprawach spoza art. 256 i 257 k.k. Przykładowo Sąd Okręgowy w Poznaniu w wyroku z 21 grudnia 2017 roku $^{76}$ wskazał, uświadamiając osoby, które - zwłaszcza za pośrednictwem internetu - miały styczność z tą sprawą, że każdy przejaw tak zwanej mowy nienawiści może skutkować odpowiedzialnością karną, internet zaś wcale nie musi zapewniać anonimowości, w obliczu której

czową krytykę". W wyroku tym Trybunał Konstytucyjny rozszerzył sferę swobody wypowiedzi, uznając za niezgodny z Konstytucją art. $226 \S 1$ k.k. w zakresie, w jakim penalizuje znieważenie funkcjonariusza publicznego lub osoby do pomocy mu przybranej dokonane niepublicznie lub dokonane publicznie, lecz nie podczas pełnienia czynności służbowych. Por. wyrok TK z dnia 11 października 2006 roku, sygn. P 3/06, 121/9/A/2006, http://ww2.senat.pl/k7/dok/trybunal/p_03_06.pdf (dostęp: 20.05.2020).

75 Odmiennie zob. T. Scheffler, Przestepstwo publicznego propagowania faszystowskiego lub innego totalitarnego ustroju państwa (art. 256 k.k.). Analiza doktrynologiczna wybranych wypowiedzi piśmiennictwa i judykatury. Czesść szczególna I, „Studia nad Autorytaryzmem i Totalitaryzmem” 40, 2018, nr 4, s. 145-159.

76 Sąd Okręgowy w Poznaniu w XVII Wydziale Karnym Odwoławczym w wyroku z 21 grudnia 2017 roku, sygn. XVII Ka 1446/17, https://www.saos.org.pl/judgments/324553 (dostęp: 20.05 . 2020).

Studia nad Autorytaryzmem i Totalitaryzmem 42, nr 1, 2020

(C) for this edition by CNS 
sprawca pozostanie bezkarny. Za wypowiedzi spełniające kryteria mowy nienawiści sąd uznał zniesławiające stwierdzenia: ,z domu rodzinnego [...]”; „A. dobrze, że ostrzegłaś mnie przed stadem S.”, „Jeśli założą mi kolejną sprawę, to będę miał możliwość widywania częściej [...] córeczkę P. i jej męża K. całego stada. Nie mogę nie opisać faktu wykrzywionych gęb; [...] p.o. Prezesa P. [...]. Wary im (te górne też) opadły i [...] fiut bombki strzelił”, a w dniu 28 lipca 2014 roku zamieścił wpis o treści „p.o. Prezesa P.N. z klanu G. i męża K. zawsze obstawiona jest, co najmniej dwoma »psami« ochronnymi", tj. przestępstw z art. $216 \S 2$ k.k.

Wskazane problemy widać jasno w sferze prawa cywilnego i ochrony dóbr osobistych. W orzeczeniach sądów cywilnych terminem „mowa nienawiści” określane są bardzo różne wypowiedzi, których właściwie jedynym wspólnym mianownikiem jest to, że mają znieważający charakter. Nie dotyczą one wyłącznie treści, lecz także zniewag i zniesławień kierowanych wobec określonych grup, na przykład celebrytki, osoby znanej publicznej ze względu danej działalności, a nawet obraźliwej wypowiedzi skierowanej do osoby publicznej, jednak nienacechowanej nienawiścią. Pewnym paradoksem jest bowiem to, że odniesienia do mowy nienawiści i próby jej zdefiniowania nie pojawiają się wyłącznie w orzecznictwie sądów karnych, lecz także w wyrokach dotyczących spraw cywilnych. Chodzi tu w przeważającej mierze o sprawy wynikające z ochrony dóbr osobistych. Problem ten wymaga jednak bardziej szczegółowej analizy.

\section{Bibliografia}

Bafia J., Mioduski K., Siewierski M., Kodeks karny, Warszawa 1977.

Brzeziński Z., Friedrich C.J., Dyktatura totalitarna, [w:] Władza i polityka. Wybór tekstów ze współczesnej politologii zachodniej, red. M. Ankwicz, Warszawa 1986.

Ćwiąkalski Z., [w:] Kodeks karny. Część szczególna. Komentarz, t. 2. Komentarz do art. 117-277 k.k., red. A. Zoll, Warszawa 2013.

Flemming M., Kutzmann W., Przestępstwa przeciwko porządkowi publicznemu, Warszawa 1999.

Gardocki L., Prawo karne, Warszawa 2001.

Gruszecka D., Kodeks karny. Część szczególna. Komentarz, red. J. Giezek, LEX 2014.

Handyside przeciwko Wielkiej Brytanii, (5493/72) [1976] ECHR 5, 7.12 .1976 r., http://hudoc.echr. coe.int/app/conversion/pdf/?library=ECHR\&id=001-57499\&filename=001-57499.pdf\&TID= fwaboyydumitemid $\% 22: \% 5 B \% 22001-57499 \% 22 \% 5 \mathrm{D} \% 7 \mathrm{D}$.

Herzog A., Kodeks karny. Komentarz, red. R.A. Stefański, Warszawa 2013.

Hitler A., Mein Kampf. Moja walka, Wrocław 2005.

Hitler A., Moja walka, Kraków 1992.

Informator Statystyczny Wymiaru Sprawiedliwości, Opracowania wieloletnie, https://isws.ms.gov. $\mathrm{pl} / \mathrm{pl} /$ baza-statystyczna/opracowania-wieloletnie.

Mamoń M., Prokuratura: To faszyzm. Są: Nie, to radykalny patriotyzm, http://czestochowa. wyborcza.pl/czestochowa/1,89625,19508506,prokuratura-to-faszyzm-sad-nie-to-radykalnypatriotyzm.html.

Marek A., Kodeks karny. Komentarz, Warszawa 2010. 
Michalska-Warias A., [w:] Kodeks karny. Część szczególna, red. M. Królikowski, R. Zawłocki, t. 2, Warszawa 2013.

Międzynarodowy pakt praw obywatelskich i politycznych uchwalony przez Zgromadzenie Ogólne

Narodów Zjednoczonych w dniu 16 grudnia 1966 roku w Nowym Jorku (Dz.U. z 1994 r.

Nr 23, poz. 80).

Mozgawa M., [w:] Kodeks karny. Komentarz, red. M. Mozgawa, Warszawa 2013.

Pływaczewski E., Sakowicz A., Kodeks karny. Część szczególna, t. 2. Komentarz do artykułów 222316, red. A. Wąsek, R. Zawłocki, Warszawa 2010.

Postanowienie Sądu Najwyższego z dnia 1 września 2011 roku, sygn. V KK 98/11, LEX nr 950444.

Postanowienie Sądu Najwyższego z dnia 5 lutego 2007 roku, sygn. IV KK 406/06, OSNwSK 2007/1/367, LEX nr 245307.

Rogalska E., Urbańczyk M., Złożoność zjawiska mowy nienawiści w pozaprawnym aspekcie definicyjnym, „Studia nad Autorytaryzmem i Totalitaryzmem”39, 2017, nr 2.

Scheffler T., Przestępstwo publicznego propagowania faszystowskiego lub innego totalitarnego ustroju państwa (art. 256 k.k.). Analiza doktrynologiczna wybranych wypowiedzi piśmiennictwa i judykatury. Część szczególna I, „Studia nad Autorytaryzmem i Totalitaryzmem” 40, $2018, \mathrm{nr} 4$.

Snyder v. Phelps, 562 U.S. 443 (2011), https://supreme.justia.com/cases/federal/us/562/443/.

Uchwała Sądu Najwyższego z dnia 28 marca 2002 roku, sygn. I KZP 5/02, OSNKW 2002/5-6/32, LEX nr 51722.

Ustawa z dnia 19 kwietnia 1969 roku - Kodeks karny (Dz.U. Nr 13, poz. 94 z późn. zm.).

Wojciechowski J., Kodeks karny. Komentarz. Orzecznictwo, Warszawa 2000.

Wypowiedzi na posiedzeniach Sejmu. Posiedzenie nr 15 w dniu 24-05-2012 (2. dzień obrad), http:// www.sejm.gov.pl/sejm7.nsf/wypowiedz.xsp?posiedzenie=15\&dzien=2\&wyp=124.

Wyrok Sądu Administracyjnego w Białymstoku VIII Wydział Karny Odwoławczy z dnia 30 czerwca 2016 roku, sygn. VIII Ka 157/16, http://orzeczenia.bialystok.so.gov.pl/content/\$N/150505000004006_VIII_Ka_000157_2016_Uz_2016-06-30_001.

Wyrok Sądu Administracyjnego w Warszawie II Wydział Karny z dnia 30 maja 2018 roku, sygn. II AKa 432/17, https://sip.lex.pl/orzeczenia-i-pisma-urzedowe/orzeczenia-sadow/ii-aka-432-17-razaca-niewspolmiernosc-kary-wyrok-sadu-522638893.

Wyrok Sądu Administracyjnego we Wrocławiu z dnia 7 marca 2013 roku, sygn. II AKa 398/12, https://sip.lex.pl/orzeczenia-i-pisma-urzedowe/orzeczenia-sadow/ii-aka-398-12-pojecie-zorganizowania-z-art-258-1-k-k-a-521416564.

Wyrok Sądu Najwyższego w Katowicach z dnia 4 sierpnia 2005 roku, sygn. II AKa 251/05, LEX nr 167924.

Wyrok Sądu Najwyższego w Katowicach z dnia 24 września 2013 roku, sygn. II AKa 301/13, LEX nr 1422288.

Wyrok Sądu Okręgowego w Poznaniu XVII Wydział Karny Odwoławczy z dnia 21 grudnia 2017 roku, sygn. XVII Ka 1446/17, https://www.saos.org.pl/judgments/324553.

Wyrok Sądu Rejonowego w Częstochowie z dnia 20 stycznia 2016 roku, sygn. IV K 24/15, http://orzeczenia.czestochowa.sr.gov.pl/content/\$N/151510050002006_IV_K_000024_2015_ Uz 2016-01-29_001.

Wyrok Sądu Rejonowego w Gdańsku (Gdańsk-Południe) Wydział II Karny z dnia 21 lipca 2017 roku, sygn. II K 528/16, https://sip.lex.pl/orzeczenia-i-pisma-urzedowe/orzeczenia-sadow/ ii-k-240-17-wyrok-sadu-rejonowego-gdansk-poludnie-w-522818186.

Wyrok Trybunału Konstytucyjnego z dnia 11 października 2006 roku, sygn. P 3/06, 121/9/A/2006, http://ww2.senat.p1/k7/dok/trybunal/p_03_06.pdf.

Wyrok Trybunału Konstytucyjnego z dnia 25 lutego 2014 roku, sygn. SK 65/12, 13/2/A/2014, https://ipo.trybunal.gov.pl/ipo/downloadOrzeczenieDoc?dok=45868.

Zoll A., Kodeks karny. Część szczególna, t. 2, Kraków 1999.

Studia nad Autorytaryzmem i Totalitaryzmem 42, nr 1, 2020

(C) for this edition by CNS 